\title{
Extent of Empowerment of the Rural Women through Various Income Generating Activities of Self-Help Groups
}

\author{
K. Asha*, S. Choudhary and I.M. Khan
}

Department of Extension Education, SKNCOA(SKNAU), Jobner-Jaipur, Rajasthan, India

\author{
*Corresponding author
}

\section{Keywords \\ Empowerment, Income generating activities, Self-help groups, Department of women and child development, Non- governmental organizations}

Article Info

Accepted:

04 June 2018

Available Online:

10 July 2018
A B S T R A C T

Women constitute half of the humanity, even contributing two-third of world's work hours. Traditionally women in almost every society have remained a second grade citizen. Hence, neither they are allowed to get themselves educated nor they are given legal rights in the property, government and in administration. Empowerment is a multi-dimensional process, which enable women or group of women to realize their full identity and power in all spheres of life. Income generating activities are considered as those initiatives that affect the economic aspects of people's lives through the use of economic tools such as credit. Self- Help Groups have emerged as one of the major strategies for women's empowerment and various schemes of the Government of India have shown that strong women's groups could contribute substantially to the development and convergence of services and activities. The present investigation was conducted in Jaipur district of Rajasthan which was selected purposively. Two Panchayat samities viz. Viratnagar and Jhotwara were selected purposively for the study, due to having maximum number of Self-Help Groups in Jaipur District. From each selected Panchayat samiti, three villages were selected randomly consisting of total 6 villages for study purpose. From each selected village two SHGs one run by DWCD and another run by NGO running from last 3-5 years and actively involved in different income generating activities consisting a total of 6 SHGs from DWCD and 6 SHGs from NGOs were selected randomly. From each SHG, 10 rural women, actively involved in the income generating activities from last 3-5 years, were selected randomly. Thus, the overall sample consisted of 120 respondents comprising 60 rural women from SHGs run by DWCD and 60 rural women from SHGs run by NGOs. An interview schedule consisting of measuring devices of dependent and independent variables along with the face data of rural women involved in the income generating activities of Self- Help Groups was prepared. The data were collected by the investigator by personally interviewing the rural women in local dialect with the help of structured interview schedule. Thereafter, data were tabulated, analyzed and inferences were drawn after subjecting the data to statistical analysis which led to the following major findings. It was found that majority of the rural women involved in the income generating activities of Self-Help Groups were having medium level of empowerment. There was 96.39 percent gain in both i.e Increase in communication ability and Human relationship maintenance ability of the respondents. The extent of empowerment through income generating activity was 65.87 per cent which indicated that still there is scope to empower the women by taking the contributing factors. 


\section{Introduction}

Empowerment is a multi-dimensional process, which enable women or group of women to realize their full identity and power in all spheres of life (Surekharao and Rajamanamma, 1999).

Traditionally women in almost every society have remained a second grade citizen. Hence, neither they are allowed to get themselves educated nor they are given legal rights in the property, government and in administration.

Income generating activities are considered as those initiatives that affect the economic aspects of people's lives through the use of economic tools such as credit. It is being increasingly realized that women's income in a family is very important in relation to the nutritional, economic and educational upliftment of the family.

Self- help groups have emerged as one of the major strategies for women's empowerment and various schemes of the Government of India have shown that strong women's groups could contribute substantially to the development and convergence of services and activities.

In Rajasthan, the Self Help movement started more as ' social mobilization' of women for their better place in family and society than as 'microfinance movement'. Most of these activities were in non-farm sector like Tailoring, dairy, goat rearing, wooden crafting, soap powder making, internal loaning, nageena work, marble work, panjiri distribution etc. Very few studies are available related to measurement of level of empowerment of women and contributing factors for it. This study entitled 'Empowerment of Rural Women through Income Generating Activities of the Self-Help Groups in Jaipur District of Rajasthan" has been designed mainly to focus on extent of empowerment of rural women through income generating activities and constraints that are experienced by rural women in their empowerment along with the factors affecting the empowerment of women through SHGs.

\section{Materials and Methods}

In the present study, the empowerment of rural women involved in the income generating activities of SHGs was measured by a schedule developed by Bharathamma (2005) with slight modifications as suggested and approved by the experts. The schedule was standardized by getting expert opinion from the experts of Department of Extension Education, Directorate of Extension Education, Department of Women and Child development and the scoring of different empowerment parameters was done as per the scores approved through expert opinion. The schedule consisted of 21 empowerment parameters namely education, land ownership, ownership of other assets (other than land), control over income contributed by her to the family, control over the income of the family, savings, access to credit, social participation, cash income earned from income generating activities (Rs $/ \mathrm{m})$, control over decision making in the family, control over planning the activities of the family, extent of increase in knowledge, extent of increase in planning ability, extent of increase in organizing ability, extent of increase in supervision ability, extent of increase in budgeting ability, extent of increase in coordinating ability, extent of increase in controlling ability, extent of increase in communication ability, extent of increase in decision making ability and extent of increase in Human -relationship maintenance ability (Appendix II Part B).

Based on the score obtained from these twenty one variables, the extent of empowerment of a particular respondent was calculated by 
summing up the scores obtained by the respondent in these 21 variables, then the empowerment index was calculated by dividing the scores by the maximum obtainable score of that particular respondent and then multiplied by 100 as follows:
Empowerment index

$($ expressed in percentage $)=$
Score obtained by a particular respondent

Maximum obtainable score by that particular

respondent
The empowerment index of a particular parameter was obtained by summing the scores obtained by all the respondents in that particular parameter and then divided by the maximum obtainable score by all the respondents in that particular parameter and multiplied by 100 .

Gain in empowerment of a particular respondent was calculated by taking difference between empowerment index value of that particular respondent before and after taking income generating activity. Then, the rural women were categorized into low empowerment, medium empowerment and high empowerment groups based on mean and standard deviation of the scores of gain in empowerment obtained by the rural women.

\section{Results and Discussion}

The findings related to the empowerment of rural women have been presented under the following headings:

Levels of empowerment of rural women involved in the income generating activities of Self-Help Groups run by DWCD and NGOs

The data presented in Table 1 indicates that majority of the rural women involved in the income generating activities of Self-Help Groups $(77.50 \%)$ were having medium level of empowerment, whereas 15.00 per cent of them were having low level of empowerment and only 7.50per cent of the respondents were having high level of empowerment. The data in the Table 1 further shows that majority of the rural women involved in the income generating activities of Self-Help Groups run by $\operatorname{DWCD}(75.00 \%)$ were having medium level of empowerment, whereas 16.67 per cent of respondents were having low level of empowerment and only 8.33 per cent of respondents were found having high level of empowerment. In case of rural women involved in the income generating activities of Self-Help Groups run by NGOs, majority of the respondents $(80.00 \%)$ were having medium level of empowerment, whereas 13.33 per cent of the respondents were having low level of empowerment and only 6.67 per cent of them were having high level of empowerment.

The analysis of the data further indicates that the ' $\chi 2$ ' value $(0.047)$ between the scores of the level of empowerment of rural women involved in the income generating activities of SHGs run by DWCD and NGOs is less than its tabulated value (5.991) at 5 per cent level of significance. Hence, the null hypothesis (Ho2.1) was accepted and the alternate hypothesis was rejected. This leads to the conclusion that there is a non-significant agreement between the level of empowerment of rural women involved in the income generating activities of Self-Help Groups run by DWCD and NGOs.

From the above findings it could be concluded that majority of the rural women involved in the income generating activities of SHGs had medium level of empowerment. This might be due to the reason that majority of these rural women had medium annual income, medium level of social participation, medium level of 
mass media participation and medium level of overall socio-economic status.

Extent of empowerment of rural women through income generating activities of Self-Help Groups run by DWCD and NGOs

A glance of Table 2 highlights the extent of empowerment of rural women involved in income generating activities of Self-Help Groups. There was 96.39 per cent gain in two parameters i.e increase in communication ability and Human relationship maintenance ability of the respondents and combindly they were ranked at first position. It was followed by 95.00 per cent increase in decision making ability, 93.06 per cent gain in coordinating ability, 91.11 per cent gain in controlling ability, 90.00 per cent gain in planning ability and were ranked third, fourth, fifth and sixth. There was 89.72 per cent gain in organizing and budgeting ability, 84.17 per cent gain in supervision ability,82.22 per cent gain in knowledge, 70.83 per cent gain in control over planning the activities of the family, 64.58 per cent gain in control over decision making in the family and were ranked seventh, ninth, tenth, eleventh and twelth. There was 52.92 per cent gain in three activities i.e control over income contributed by the rural women in their family, control over income of the family and access to credit, 50.00 per cent gain in both i.e ownership of the assets and savings, 38.61 per cent gain in social participation, 20.24 per cent gain in increase in cash income earned from income generating activities, 15.00per cent gain was found in the land ownership of the rural women and the least gain (7.4per cent) was found in education and were ranked thirteenth, sixteenth, eighteenth, nineteenth, twentieth and twenty first.

Table 2 further highlights the extent of empowerment of rural women involved in income generating activities of SHGs run by
DWCD. There was highest gain (96.11\%) gain in two parameters i.e increase in communication ability and Human relationship maintenance ability of the respondents and combindly they were ranked at first position, whereas in case of rural women involved in the income generating activities of SHGs run by NGOs there was 96.66 per cent gain in both of these parameters.

In case of the rural women involved in the income generating activities of SHGs run by DWCD 95.00 per cent increase in decision making ability was observed followed by 92.78 per cent gain in coordinating ability, 90.56 per cent gain in controlling ability, 90.00 per cent gain in planning ability, 89.44 per cent gain in organizing and budgeting ability and were ranked third, fourth, fifth, sixth and seventh. There was 83.33 per cent gain in supervision ability followed by 81.11 per cent gain in knowledge, 71.67 per cent gain in control over planning the activities of the family, 64.17 per cent gain in decision making in the family, 53.33 per cent gain in three activities i.e control over income contributed by the rural women in their family, control over income of the family and access to credit and were ranked ninth, tenth, eleventh, twelfth and thirteenth. There was 50.00 per cent gain in both i.e. ownership of the assets and savings followed by 38.88 per cent gain in social participation, 21.43 per cent gain in cash income earned, 15.00 per cent was found in the land ownership of the rural women and the least gain (7.29 per cent) was found in education and were ranked sixteenth, eighteenth, nineteenth, twentieth and twenty first.

In case of rural women involved in the income generating activities of SHGs run by NGOs, there was 95.00 per cent increase in decision making ability was found followed by 93.33 per cent gain in coordinating ability, 91.67 per 
cent gain in controlling ability, 90.00 per cent gain in planning ability, organizing and budgeting ability and were ranked third, fourth, fifth and sixth. There was 85.00 per cent gain in supervision ability followed by 83.33 per cent gain in knowledge, 70.00 per cent gain in control over planning the activities of the family, 65.00 per cent gain in control over decision making in the family, 52.50 per cent gain in three activities i.e control over income contributed by the rural women in their family, control over income of the family and access to credit and were ranked ninth, tenth, eleventh, twelfth and thirteenth. There was 50.00 per cent gain in both i.e. ownership of the assets and savings followed by 38.33 per cent gain in social participation, 19.05 per cent gain in cash income earned from income generating activities, 15.00 per cent gain was found in the land ownership of the rural women and the least gain (7.5 per cent) was found in education and were ranked sixteenth, eighteenth, nineteenth, twentieth and twenty first.

The analysis of the data further indicates that the calculated value of ' $t$ ' (4.4095) between the scores of gain in empowerment of rural women involved in the income generating activities of SHGs run by DWCD and NGOs is more than its tabulated value (2.845) at 1 per cent level of significance. Hence, the null hypothesis (Ho2.2) was rejected and the alternate hypothesis was accepted. This leads to the conclusion that there is a highly significant difference between the gain in empowerment of rural women involved in the income generating activities of Self-Help Groups run by DWCD and NGOs.

Table.1 Distribution of rural women involved in income generating activities of Self-Help Groups run by DWCD and NGOs according to their level of empowerment $\mathrm{N}=120$

\begin{tabular}{|c|c|c|c|c|c|c|c|}
\hline \multirow[t]{2}{*}{ S.No. } & \multirow[t]{2}{*}{$\begin{array}{c}\text { Levels of } \\
\text { empowerment }\end{array}$} & \multicolumn{2}{|c|}{$\begin{array}{l}\text { Rural women of SHGs } \\
\text { run by DWCD }(\mathrm{N}=60)\end{array}$} & \multicolumn{2}{|c|}{$\begin{array}{l}\text { Rural women of } \\
\text { SHGs run by NGO } \\
(\mathrm{N}=60)\end{array}$} & \multicolumn{2}{|c|}{$\begin{array}{l}\text { Total respondents } \\
\qquad(\mathrm{N}=120)\end{array}$} \\
\hline & & $\mathbf{F}$ & Per cent & F & Per cent & $\mathbf{F}$ & Per cent \\
\hline 1. & $\begin{array}{l}\text { Low (less than } 53.05 \\
\text { score) }\end{array}$ & 10 & 16.67 & 8 & 13.33 & 18 & 15.00 \\
\hline 2. & $\begin{array}{l}\text { Medium ( } 53.05 \text { to } \\
67.53 \text { score) }\end{array}$ & 45 & 75.00 & 48 & 80.00 & 93 & 77.50 \\
\hline 3. & $\begin{array}{l}\text { High (more than } \\
67.53 \text { score) }\end{array}$ & 5 & 8.33 & 4 & 6.67 & 9 & 7.50 \\
\hline & Total & 60 & 100.00 & 60 & 100.00 & 120 & 100.00 \\
\hline
\end{tabular}

Tabulated value of $\chi^{2}$ at 5 per cent level of significance $=5.991$ 
Table.2 Extent of empowerment of rural women through income generating activities of selfhelp groups run by DWCD and NGOs with respect to different parameters of empowerment

\begin{tabular}{|c|c|c|c|c|c|c|c|c|c|c|c|c|c|}
\hline \multirow{4}{*}{ S. No. } & \multirow{4}{*}{ Parameters of empowerment } & & & & & & & & & & \multicolumn{3}{|c|}{$\mathrm{N}=120$ (Multiple response) } \\
\hline & & \multicolumn{4}{|c|}{ Rural women of SHGs run by DWCD } & \multicolumn{4}{|c|}{ Rural women of SHGs run by NGO } & \multicolumn{4}{|c|}{ Total respondents (N=120) } \\
\hline & & $\begin{array}{c}\text { Index } \\
\text { value } \\
\text { (Before) }\end{array}$ & $\begin{array}{l}\text { Index } \\
\text { value } \\
\text { (After) }\end{array}$ & $\begin{array}{c}\text { Gain in } \\
\text { Empower } \\
\text { ment }\end{array}$ & Rank & $\begin{array}{c}\text { Index } \\
\text { value } \\
\text { (Before) }\end{array}$ & $\begin{array}{l}\text { Index } \\
\text { value } \\
\text { (After) }\end{array}$ & $\begin{array}{c}\text { Gain in } \\
\text { Empower } \\
\text { ment }\end{array}$ & Rank & $\begin{array}{c}\text { Index } \\
\text { value } \\
\text { (Before) }\end{array}$ & $\begin{array}{l}\text { Index } \\
\text { value } \\
\text { (After) }\end{array}$ & $\begin{array}{c}\text { Gain in } \\
\text { Empower } \\
\text { ment }\end{array}$ & Rank \\
\hline & & (MPS) & (MPS) & (MPS) & & (MPS) & (MPS) & (MPS) & & (MPS) & (MPS) & (MPS) & \\
\hline 1 & Education & 45.63 & 52.92 & 7.29 & $X X \mid$ & 45 & 52.5 & 7.5 & $X X \mid$ & 45.31 & 52.71 & 7.4 & $X X \mid$ \\
\hline 2 & Land ow nership & 1.67 & 16.67 & 15 & $X X$ & 2.5 & 17.5 & 15 & $X X$ & 2.08 & 17.08 & 15 & $X X$ \\
\hline 3 & $\begin{array}{l}\text { Ow nership of other assets (other } \\
\text { than land) }\end{array}$ & 0 & 50 & 50 & $X V I$ & 0 & 50 & 50 & $X V I$ & 0 & 50 & 50 & $X V I$ \\
\hline 4 & $\begin{array}{l}\text { Control over income contributed by } \\
\text { her to the family }\end{array}$ & 0 & 53.33 & 53.33 & $X \| 11$ & 0 & 52.5 & 52.5 & $X \| 11$ & 0 & 52.92 & 52.92 & $X \| 11$ \\
\hline 5 & $\begin{array}{l}\text { Control over the income of the } \\
\text { family }\end{array}$ & 0 & 53.33 & 53.33 & $X \mid 1$ & 0 & 52.5 & 52.5 & $X \| 11$ & 0 & 52.92 & 52.92 & $X \| 11$ \\
\hline 6 & Savings & 0 & 50 & 50 & $X V I$ & 0 & 50 & 50 & $X V I$ & 0 & 50 & 50 & $X V I$ \\
\hline 7 & Access to credit & 0 & 53.33 & 53.33 & $X \| 11$ & 0 & 52.5 & 52.5 & $X \| 11$ & 0 & 52.92 & 52.92 & $X \| 11$ \\
\hline 8 & Social participation & 0.56 & 39.44 & 38.88 & $X V \|$ & 0 & 38.33 & 38.33 & $X V \|$ & 0.28 & 38.89 & 38.61 & $X V \|$ \\
\hline 9 & $\begin{array}{l}\text { Cash income earned fromincome } \\
\text { generating activities (Rs/month) }\end{array}$ & 0 & 21.43 & 21.43 & $X I X$ & 0 & 19.05 & 19.05 & XIX & 0 & 20.24 & 20.24 & $X I X$ \\
\hline 10 & $\begin{array}{l}\text { Control over decision making in the } \\
\text { family }\end{array}$ & 0 & 64.17 & 64.17 & $X \|$ & 0 & 65 & 65 & $X \|$ & 0 & 64.58 & 64.58 & $X \|$ \\
\hline 11 & $\begin{array}{l}\text { Control over planning the activities } \\
\text { of the family }\end{array}$ & 0 & 71.67 & 71.67 & $X \mid$ & 0 & 70 & 70 & $X \mid$ & 0 & 70.83 & 70.83 & $\mathrm{XI}$ \\
\hline 12 & Extent of increase in know ledge & 1.11 & 82.22 & 81.11 & $x$ & 0 & 83.33 & 83.33 & $x$ & 0.56 & 82.78 & 82.22 & $x$ \\
\hline 13 & Extent of increase in Planning ability & 2.78 & 92.78 & 90 & $\mathrm{VI}$ & 1.67 & 91.67 & 90 & $\mathrm{VI}$ & 2.22 & 92.22 & 90 & $\mathrm{Vl}$ \\
\hline 14 & $\begin{array}{l}\text { Extent of increase in organizing } \\
\text { ability }\end{array}$ & 2.78 & 92.22 & 89.44 & VII & 1.67 & 91.67 & 90 & $\mathrm{VI}$ & 2.22 & 91.94 & 89.72 & $V \|$ \\
\hline 15 & $\begin{array}{l}\text { Extent of increase in Supervision } \\
\text { ability }\end{array}$ & 2.78 & 86.11 & 83.33 & IX & 1.67 & 86.67 & 85 & IX & 2.22 & 86.39 & 84.17 & IX \\
\hline 16 & $\begin{array}{l}\text { Extent of increase in budgeting } \\
\text { ability }\end{array}$ & 2.78 & 92.22 & 89.44 & VII & 1.67 & 91.67 & 90 & $\mathrm{VI}$ & 2.22 & 91.94 & 89.72 & $V \|$ \\
\hline 17 & $\begin{array}{l}\text { Extent of increase in coordinating } \\
\text { ability }\end{array}$ & 2.78 & 95.56 & 92.78 & N & 1.67 & 95 & 93.33 & N & 2.22 & 95.28 & 93.06 & N \\
\hline 18 & $\begin{array}{l}\text { Extent of increase in controlling } \\
\text { ability }\end{array}$ & 1.67 & 92.22 & 90.56 & V & 0 & 91.67 & 91.67 & V & 0.83 & 91.94 & 91.11 & V \\
\hline 19 & $\begin{array}{l}\text { Extent of increase in communication } \\
\text { ability }\end{array}$ & 2.78 & 98.89 & 96.11 & I & 1.67 & 98.33 & 96.66 & I & 2.22 & 98.61 & 96.39 & 1 \\
\hline 20 & $\begin{array}{l}\text { Extent of increase in decision } \\
\text { making ability }\end{array}$ & 2.78 & 97.78 & 95 & $\|$ & 1.67 & 96.67 & 95 & $\|$ & 2.22 & 97.22 & 95 & $\|$ \\
\hline 21 & $\begin{array}{l}\text { Extent of increase in Human- } \\
\text { relationship maintenance abbility. }\end{array}$ & 2.78 & 98.89 & 96.11 & I & 1.67 & 98.33 & 96.66 & I & 2.22 & 98.61 & 96.39 & 1 \\
\hline & Overall gain in empowerment & 3.47 & 69.29 & 65.82 & & 2.9 & 68.8 & 65.9 & & 3.18 & 69.05 & 65.87 & \\
\hline
\end{tabular}

4' value $=4.4095^{* *}$ ( ${ }^{* *}$ Significant at 5 per cent level of significance) $\quad$ d. $f=20$

Tabulated value of ' $\mathrm{t}$ ' at 1 per cent level of significance $=2.845$

Tabulated value of ' 1 ' at 5 per cent level of significance $=2.086$ 
This clearly revealed the fact that, income generating activities significantly contributed for empowerment of rural women. Further, the data also revealed that there was 65.87 per cent gain in empowerment after taking income generating activity.

A thorough analysis of components of empowerment revealed that considerable percentage of rural women became able to maintain human relationships and increased their communication ability. Apart from this women were able to earn money through income generating activities which facilitated them to control money earned by them independently. It also enhanced saving habit of rural women. These factors have contributed significantly for gain in empowerment. In addition the accessibility of rural women to formal financial credit institutions was also enhanced due to taking up income generating activities. Being a member of SHG, respondents participated in various extension activities like trainings, meetings, educational tours, demonstrations, exhibitions and krishimela / kisanmela. This leads to increase in knowledge, skill and communication behaviour of rural women.

\section{References}

Bharathamma, G.U., Angadi, J.G., Hirevenkanagoudar, L.V. and Natikar, K.V. (2006). "Empowerment of rural women through income generating activitie." Karnataka Journal of Agricultural Sciences; 19(3):600-602

Chawla,S. and Chanderbhan. (2014). "Economic Empowerment of Rural Women through Self Help Groups". Abstract: $7^{\text {th }}$ National Extension Education Congress on "Translational Research - Extension for sustainable Small Farm Development" 08-11, November, 2014

Esakkimuthu, M. (2015). "Economic empowerment of women through
SHGs". Abstract: National seminar on "Extension Innovations and methodologies for market-led Agricultural Growth and Development". 26-28 February 2015. Haque,M., Sahariya, K.K. and Khuman L.S. (2014). "Poultry Entrepreneur of SHG Members After bank Linkage against Inflation in Darrang and Kamrup Districts of Assam". Abstract: $7^{\text {th }}$ National Extension Education Congress on "Translational Research - Extension for sustainable Small Farm Development".08-11 November,2014

Jyothi, K. S. (1998). "Employment pattern and empowerment of rural women - A study in Kolar district." M.Sc. (Agri.) Thesis, University of Agricultural Sciences, Bangalore.

Rahman, Rahman M.I., Uddin M.M., Alam, A.B.M.S. and Kamaly, M.B. (2012). "Empowerment of rural women through participation in Income generating activities for maintaining livelihood." Journal of Socio-economic Research and Development,9(6):14091417.

Rewani, S.K., Mahto, V.K., Oraon, J. and Pandey, A.K. (2015). "Economic empowerment of women through livestock based entrepreneurial activities of self-help groups". Abstract: National seminar on "Extension Innovations and methodologies for market-led Agricultural Growth and Development" 26-28 February 2015

Saradha, O. (2001). "Empowerment of rural women through self-help groups in Prakasam district of Andhra Pradesh An analysis." M. Sc. (Agri.) Thesis, University of Agricultural Sciences, Bangalore.

Sherin, K.J. (1999). "Dynamics of self-help group formation - A case study in Thrissur district." M.Sc. (Agri.) Thesis, 
Kerala

University, Thrissur.

Sharma, N., Singh, A., Upadhyay, S.,K. and

Kumar, S. (2014).“ Social Empowerment of Women through Self Help Groups: An impact assessment". Abstract: $7^{\text {th }}$ National Extension Education Congress on "Translational Research - Extension for sustainable Small Farm Development”, 08-11 November 2014.

Singh, A., Sharma, S.K, Henry, C and Rathore, R. (2014). "Constraints Encountered by Women Member in Operating Various Enterprises in SHGs". Abstract: $7^{\text {th }}$ National Extension Education Congress on "Translational Research - Extension for sustainable Small Farm Development”. 08-11 November, 2014.

Singh, D.V. (2015). "Social empowerment of women through Self Help Groups: An impact assessment". Abstract: National seminar on "Extension Innovations and methodologies for market-led Agricultural Growth and Development". 26-28 February, 2015.

Wason, Singh, M., Premlata, Padaria, R. N., Sangeetha, V., Sharma, N., Gupta, S. and Chaturvedi, V. K. (2015). "Designing and Validating capacity building modules for enhancing effectiveness and sustainability of SHGs for gender empowerment". Abstract: National seminar on "Extension Innovations and methodologies for market-led Agricultural Growth and Development" 26-28 February, 2015.

Yogi, R. K., Singh, J. P., Singh, A. K., Jaiswal, A. K., and Sequeira, Daphne. (2014). "Triggering Profitability and Small Scale Entrepreneurship in Natural Resin Production: A SHG Approach in Khunti District". Abstract: $7^{\text {th }}$ National Extension Education Congress on "Translational Research - Extension for sustainable Small Farm Development", 08-11 November, 2014

\section{How to cite this article:}

Asha, K., S. Choudhary and Khan, I.M. 2018. Extent of Empowerment of the Rural Women through Various Income Generating Activities of Self-Help Groups. Int.J.Curr.Microbiol.App.Sci. 7(07): 217-224. doi: https://doi.org/10.20546/ijcmas.2018.707.026 